\section{Annual Review of Microbiology}

Vol. 16. Edited by Charles E. Clifton in association with Sidney Raffel and Mortimer P. Starr. Pp. vii +344. (Palo Alto, Calif.: Annual Reviows, Inc., 1962.) 7 dollars.

IN the introduction to the first volume of Annual 1 Reviews of Microbiology the editors expressed the hope that subsequent editions would serve the need of microbiologists of diverse interests by providing summa. ries of work in many different fields. That the present volume deals only with a limited number of topies is not entirely the fault of the editors, who had planned a more varied list of contents, and it does not necessarily detract from its value to the average microbiologist. The specialization of subject-matter which characterizes this year's Annual Review has the advantage that it provides a comprehensive account of the selected topics. Thus four reviews are concerned with aspects of microbial genetics. This very important subject is discussed from various points of view, ranging from descriptions of the sex life of bacteria and Aspergillus to an account of the biochemical mechanisms of gene action.

Immunological topies are also given generous treatment in this book. A fascinating contribution on the elaboration of antibodies by single cells gives rise to the hope that those genotical and biochemical methods which have been so successful in studying microbial biosynthesis may eventually be applied to such systems. Such an investigation would require more knowledge than we possess at present of the specialized structure of antibody proteins; much recent progress has been made in this field and this is described in an article on the nature of antibodies and antigens. The effects of specific antibodies on tissue cells are discussed in a review of that title and also in an article on cultural characterization of tissue cells where the use of these specific reactions for the practical purposes of identifying cells is described.

A few reviews on more classical aspects of microbiology help to counterbalance the large number of articles devoted to these two specialized topics. Thus "Endogenous Metabolism of Microorganisms" and "Lipid Requirements of Microorganisms" both provide valuable summaries of information collected from widely distributed sources. A subject of personal importance as well as general interest to microbiologists is described in a survey of the methods for control and purification of water. The difficulties which beset workers with oncogenic viruses are brought out in a very clear account of the complex subject of viral leukæmias of mice.

Although this volume undoubtedly provides reviews of interest to most microbiologists it is to be hoped that next year's edition will show a return to the original editorial policy.

A. Newton

\section{Histogenetische Studien an den Blüten Einiger Phanero- gamen}

Von Dr. Helmut Pankow. (Botanische Studien, Heft 13.)

Pp. v + 106. (Jena: Veb Gustav Fischer Verlag, 1962.) $14.30 \mathrm{DM}$.

THIS volume is one of a series, edited by Profs. W. Troll and $\mathbf{H}$. von Guttenberg, which is intended for the publication of investigations requiring more extensive treatment than is usually possible in most botanical periodicals. The present contribution is concerned almost exclusively with histogenetic investigations on the ovary, and in particular on the ovules, in a considerable range of angiosperm species. A few gymnosperms were also examined.

In his introduction to this investigation the author rightly stresses that with regard to the morphological interpretation of the angiosperm flower there have been more speculations than serious attempts to ascertain the available facts. It is also pointed out that although in dealing with a structure so complex as the angiosperm flower no line of evidence should be ignored, there have been relatively few investigations of the development of the ovary or ovule. In his own contribution to this field, the author has now provided us with detailed wellillustrated accounts of the development of the ovules and associated structures in a number of representative species from 23 families of angiosperms.

Although the author's personal investigations constitute the greater part of the work, there is also a concise review of other investigations of gynœeium development. From his own investigations the author concludes that in many families the ovules are clearly stachyosporous, that is, originate from cauline tissue, while in other families they are phyllosporous and originate from the carpels. Too much emphasis is not placed on this distinction, and the author draws an analogy with Selaginella in which some species have axillary sporangia produced from stem tissue, while other species bear sporangia on leaf tissue at the base of the sporophyll.

The entire work is a valuable factual contribution to our knowledge of gynœcium development and on that basis is a useful addition to any botanical library.

A Allsope

\section{Life of the Wayside and Woodland}

A Seasonal Guide to the Natural History of the British Isles. By Dr. T. R. E. Southwood. A. new edition based on the work of T. A. Coward. (The Wayside and Woodland Series.) Pp. xii $+290+64$ plates. (London and New York: Frederick Warne and Co., Ltd., 1963.) $30 s$. net.

THIS is a now edition of Life of the Wayside and Woodland, based on the work of T. A. Coward. Although the greater part of the original text has had to be changed, as a result of vast research over the past forty years, this edition should have as wide an appeal as earlier ones. The book is intended to serve as a general introduction to natural history, as well as to act as a reference book for more advanced scholars, or those training to teach. It should also promote interest in, and act as a guide to, practical field study. The text throughout is straightforward. Scientific names are given where appropriate, as they are international: they do not complicate the simplicity, and should serve as a preparatory aid for more advanced study.

The major proportion of the book is made up by dividing the year into six two-monthly sections, and dealing with whatever 'life' is flourishing at that particular time. A very wide range of life is covered.

Following this major section are four appendixes. Appendix 1 gives some common galls, leaf mines and other types of leaf damage: this is most interesting and could in itself stimulate observation. Appendix 2 outlines the Berlese-Tullgren funnel operation for the extraction of animals from soil, plant debris and dung. Appendix 3 gives the names of natural history societies, while Appendix 4 gives classified lists of books for further study. This is followod by an index.

There are 32 plates in colour and 32 in black-and-white. Also there are more than 300 text figures which are very clear and give ample illustration throughout.

\section{B. J. G. Maitland}

\section{Lasers}

Generation of Light by Stimulated Emission. By Bela A. Lengyel. (Wiley Series in Pure and Applied Optics.) Pp. xi +125 . (New York and London: John Wiley and Sons, Inc., 1962.) 55s.

7 FIS appears to be the first book specifically devoted to masers working in the optical domain. It was written during a period of great activity in the field and the author realizes that it "will necessarily have a limited useful lifetime". At the timo of writing there were very few sources other than the original publications to which 